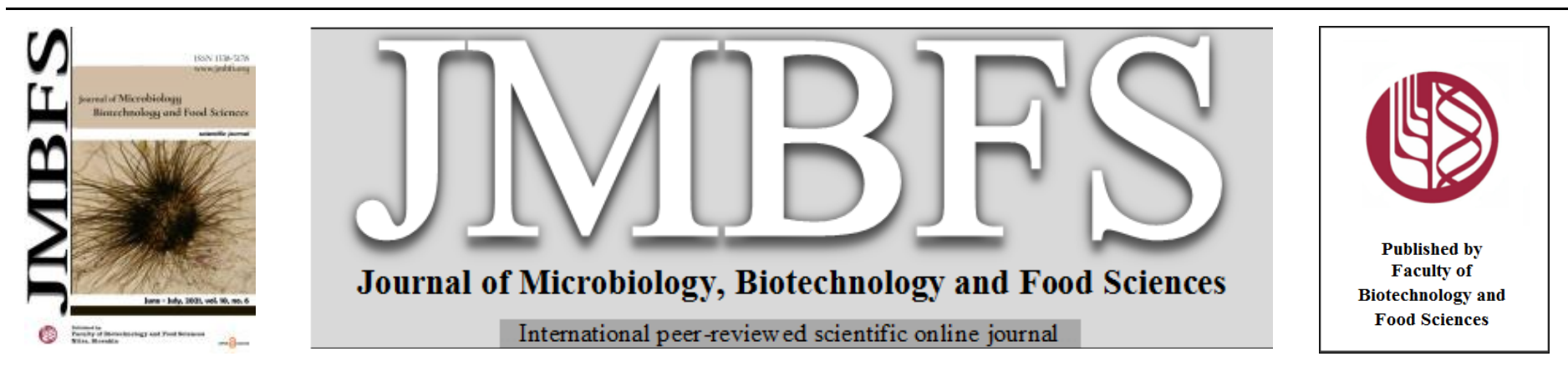

\title{
OPTIMIZATION of a NEW MEDIUM of WHEY WATER and SWEET POTATO EXTRACT fOr DIFFERENT LACTOBACILLUS SPECIES by PLACKETT-BURMAN STATISTICAL DESIGN USING MINI -TAB16 SOFTWARE
}

\author{
Amel Ibrahim ${ }^{1 *}$ and Abeer I.M. EL-Sayed ${ }^{2}$
}

Address(es): Amel Ibrahim, phD.,

${ }^{1}$ Dairy Microorganisms and Cheese Research Laboratory (DMCR), Department of Dairy Science and Technology, Faculty of Agriculture (El-Shatby), Alexandria University, Alexandria 21545, Egypt.

${ }^{2}$ Botany and microbiology Department, Faculty of Science, Damanhour University, El bahira, Egypt.

*Corresponding author: amal.ibrahim@alexu.edu.eg

https://doi.org/10.15414/jmbfs.2487

\section{ARTICLE INFO}

Received 23. 12. 2020

Revised 10. 1. 2021

Accepted 20.1.2021

Published 1. 6. 2021

Regular article open $\mathcal{C}_{\text {ACCESS }}$

\begin{abstract}
An attempt is made to use cheese whey water (Ww) and sweet potato extract (SPE) separately or in combination to manipulate a cheap and economical media component for large scale production of lactobacilli. Primarily, lactobacilli species were cultivated on de-Man Rogosa and Sharp medium (MRS) then, these strains were grown in (SPE) and (Ww) using a flask fermentation technique at $37^{\circ} \mathrm{C}$, followed by applying a statistical experimental design (Plackett- Burman (PB)) via a statistical software MiniTab16 to optimize the media constituents for achieving a large scale production of lactobacilli; with studying the main effect of medium components referring to the most critical nutritional factors in the newly organized medium. Generally, our results indicated that both sweet potato and whey water extract (SPWE); could be used for the growth of lactobacilli instead of (MRS) medium. Further, other experiments were done to show how lactobacilli growth will be affected by $\mathrm{pH}$ and various types of whey; using standard plate count method. Highest counts for Lactobacillus acidophilus (2r) and Lactobacillus rhamnosus (190RZFAAU) were at pH 6 and pH 6.5 in (SPWE) medium. Depending on the above investigations; (SPWE) medium including the addition of different types; whey water can be used as an alternative growth medium for lactobacilli instead of MRS which was traditionally used for growing these kinds of Lactic acid bacteria (LAB). Additionally, findings in this study can help in cleaning our environment from the huge disposal quantities of whey resulted as byproduct from cheese industries.
\end{abstract}

Keywords: Lactobacilli, Sweet potato, Whey, probiotics, Antimicrobial, Plackett- Burman

\section{INTRODUCTION}

(LAB) including lactobacilli species can produce lactic acid (LA) as a main end product of lactose fermentation. Also; these remarkable species serve as a functional starter culture in food fermentation process, by acting as probiotics and bio-preservatives leading to an improvement in the human health. (Leroy and De Vuyst, 2004).

It is well known that various types of whey (sweet whey, salted whey and acid whey) are the most contaminating waste product resulted during cheese manufacture. Sweet whey can share in some industrial food applications (Ryan and Walsh, 2016), while, acid whey processing is problematic at any scale due to the differences in both composition and electrostatic protein interactions (Chandrapala et al., 2015). Additionally, sweet whey is unlike salty whey which represents a crisis in Egypt due to high quantity of useless salted whey, it has a high biological oxygen demand and chemical oxygen demand, resulting in a disposal problem, is a problem also cannot be conveniently processed due to its high salinity level (El-Tanboly et al.,2012 ; Awad et al., 2013). Therefore, a preferable solution for that; is to use the whey as a growth media regarding its high nutritional value. A very interesting and challenging target; is to elicit an alternative cheap cultivation media for lactobacilli species, which are known as the most stringent bacterial group in applied microbiology (lactobacilli); due to their fastidious nutritional needs; which are costly especially in the large-scale production. (Hayek et al.,2013) .

Sweet potato (Ipomoea batatas) is an abundant available agricultural product rich with many nutrients: as carbohydrates (mainly Starch and sugars), amino acids, vitamins, minerals (calcium, iron, magnesium, phosphorous, potassium, sodium and zinc) and dietary fibers (Hayek et al.,2013).

Depending on the nutritional profile of sweet potatoes, which contain Lactobacillus stimulating factors such as triglycerides, linoleic acid, palmitic acid and Oleic acid (Loebenstein and Thottappilly, 2009), Consequently, Sweet potatoes can be used as a significant component in the newly formulated Lactobacilli culture medium (Duda-Chodak et al.,2008).

The main objective of this study is to examine the supplementation of whey and sweet potato individually and in combination as basic components in designing a low-cost culture medium for Lactobacillus growth. Additionally, this study is made to check the effect of various types of whey (acid, salted and sweet whey) and sweet potato extract either separately or both are combined together on lactobacilli growth.

\section{MATERIALS AND METHODS}

\section{Lactobacilli strains}

Five lactobacilli strains are used in this study; were previously studied for their application in dairy industry as probiotic culture and antimicrobial producer (Table 1). Lactobacillus rhamnosus 190 RZFAAU and 130RZFAAU; L. acidophilus $2 \mathrm{r}$ were obtained from Faculty of Agriculture Alexandria University culture collection; L. rahmnosus (SACOO Lyofast SP1), L. acidophilus (CHR.HANSEN, Nu-trish LA-5). Lactobacilli strains were propagated in sterile MRS broth (Biolife, Italy) as a control medium and incubated for $24 \mathrm{~h}$ at $37^{\circ} \mathrm{C}$. 
Table 1 Lactobacillus strains used in this stu

\begin{tabular}{lccl}
\hline Strain No & Identification & Application in dairy products & Reference \\
\hline 190RZFAAU & Lactobacillus rhamnosus & Antimicrobial activity against Staphylococcus aureus & (Ibrahim and Awad, 2017). \\
130RZFAAU & Lactobacillus rhamnosus & Antimicrobial activity against Staphylococcus aureus & (Ibrahim and Awad ,2017). \\
SP1 & Lactobacillus rhamnosus $G G$ & Probiotic culture & Shori(2016) \\
LA-5 & Lactobacillus acidophilus & Probiotic culture & Shah (2004) \\
2r & Lactobacillus acidophilus & Probiotic culture & (Mahrous and Abd-El-Salam ,2014). \\
\hline
\end{tabular}

\section{Whey Collection}

Ras cheese whey (salted whey) samples were obtained during the Ras cheesemanufacturing process in Dairy pilot plant, Agriculture faculty, Alexandria University, Egypt. Vegetable oil Ras cheese whey (salted whey) and Mozzarella cheese whey (sweet whey) were collected from El bdya factory, EL Behira governate, Egypt. Acid whey was prepared in laboratory by using lemon juice

\section{Physiochemical analysis of whey}

$\mathrm{pH}$, Total solid, moisture, lactose and salt content of whey samples were determined according to standard methods AOAC (2005).

\section{Whey water preparation}

All types of whey were heated at $100^{\circ} \mathrm{C}$ for $30 \mathrm{~min}$. Precipitated proteins were removed by centrifugation at $4,000 \mathrm{rpm}$ for $15 \mathrm{~min}$.

\section{Sweet potato extract}

Sweet potatoes were obtained from local market, after baking at $200{ }^{\circ} \mathrm{C}$ for $2 \mathrm{~h}$ then sweet potatoes mixed with distilled water in kitchen mixer for $5 \mathrm{~min}$ at ratio of 2:1 distilled water (ml) to Sweet potatoes (g). (SPE) was collected after centrifugation of mixture at $7800 \mathrm{xg} / 20 \mathrm{~min}$. (SPWE) were prepared as previous but dissolved in whey water instead of water.

\section{Experimental design and statistical analysis}

\section{Plackett - Burman design by Mini-Tab 16}

The present study aimed at the designing of an optimized medium for enhancing the growth of the Lactobacilli. For this purpose, the modified MRS medium was used as the basal medium and was further supplemented with some simple media constituents. In order to study the effect of these constituents on the growth of Lactobacillus strains, a Plackett- Burman design was used Plackett and Burman (1946). The statistical software MiniTab16 was used to study their interactions and to find out their optimal values. The PB

design has proved to be very effective and is widely used to identify significan variables $(>5)$ with minimum of testing. Each variable is represented at two coded levels (1 and -1) as shown in Table 2. Each column should contain equal number of positive and negative signs. Eight variables were screened in twelve trials.

The effect of each variable and their interactions on cell growth were studied through statistical analysis using the analysis of variance (ANOVA).

\section{Culture media preparation}

Treated whey water (Ww) and sweet potato extract (SPE) separately or in combination were used as three different dissolvent solutions for other MRS media components except glucose and peptone. According to Plackett - Burman statistical design the eight medium components (Beef extract, yeast extract, di potassium hydrogen phosphate, sodium acetate, di ammonium citrate, magnesium sulfate, manganous sulfate and tween 80) were dissolved with different concentrations in treated whey water (Ww), sweet potato extract (SPE) separately and in combination (SPWE) (Table 2). Culture media were prepared as per the statistical design (Table 2) then sterilization at $121^{\circ} \mathrm{C}$ for $15 \mathrm{~min}$.

\section{Lactobacilli enumeration in different tested media}

Thirty-six different experimental statistical designs and the MRS control trail were inoculated with $1 \%$ of the active lactobacilli strains. Bacterial growth was monitored by measuring the optical density at $650 \mathrm{~nm}\left(\mathrm{OD}_{650}\right)$ using a spectrophotometer (NOVA SPEC II, Pharmacia LKB Biotech., UK) during 6 hr.

Table 2 Plackett - Burman experimental design matrix for eight variables
Variables $(\mathrm{g} / \mathrm{L})$

\begin{tabular}{|c|c|c|c|c|c|c|c|c|c|c|}
\hline$\stackrel{*}{\stackrel{*}{g}}$ & 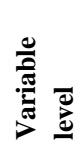 & $\begin{array}{l}-1 \\
+1\end{array}$ & $\begin{array}{c}\begin{array}{c}\text { Beef } \\
\text { extract }\end{array} \\
5 \\
10\end{array}$ & $\begin{array}{c}\text { Yeast } \\
\text { extract } \\
0 \\
5\end{array}$ & $\begin{array}{c}\mathrm{K}_{2} \mathrm{HPO}_{4} \\
0 \\
2\end{array}$ & $\begin{array}{c}\text { Sodium } \\
\text { acetate } \\
0 \\
5\end{array}$ & $\begin{array}{c}\text { Di-ammonium } \\
\text { citrate } \\
0 \\
2\end{array}$ & $\begin{array}{c}\mathrm{MgSO}_{4} \\
0 \\
0.2\end{array}$ & $\begin{array}{c}\text { Manganous } \\
\text { sulfate } \\
0 \\
0.05\end{array}$ & $\begin{array}{c}\text { Tween80 } \\
(\mathbf{m l}) \\
\mathbf{0} \\
\mathbf{1}\end{array}$ \\
\hline 1 & & & 5 & 5 & 0 & 0 & 0 & 0.2 & 0.05 & 1 \\
\hline 2 & & & 5 & 0 & 0 & 0 & 0 & 0 & 0 & 0 \\
\hline 3 & & & 10 & 5 & 2 & 0 & 2 & 0.2 & 0 & 1 \\
\hline 4 & & & 10 & 5 & 0 & 5 & 2 & 0 & 0.05 & 0 \\
\hline 5 & & & 10 & 5 & 0 & 5 & 0 & 0 & 0 & 1 \\
\hline 6 & & & 10 & 0 & 2 & 5 & 0 & 0.2 & 0 & 0 \\
\hline 7 & & & 10 & 0 & 2 & 0 & 0 & 0 & 0.05 & 1 \\
\hline 8 & & & 5 & 5 & 2 & 5 & 0 & 0.2 & 0.05 & 0 \\
\hline 9 & & & 5 & 0 & 0 & 5 & 2 & 0.2 & 0 & 1 \\
\hline 10 & & & 5 & 0 & 2 & 5 & 2 & 0 & 0.05 & 1 \\
\hline 11 & & & 10 & 0 & 0 & 0 & 2 & 0.2 & 0.05 & 0 \\
\hline 12 & & & 5 & 5 & 2 & 0 & 2 & 0 & 0 & 0 \\
\hline
\end{tabular}

*Each trial is culture media /set

\section{Effect of different $\mathrm{pH}$ on selected Lactobacilli strains}

The effect of initial $\mathrm{pH}$ was studied by adjusting the $\mathrm{pH}$ of the tested statistically designed media with the maximum count at different $\mathrm{pH}$ values: 5.5, 6, 6.5 and 7 using $1 \mathrm{~N} \mathrm{HCL}$ and $1 \mathrm{~N} \mathrm{NaOH}$. Flasks were incubated at $37^{\circ} \mathrm{C}$ for 6 and $24 \mathrm{hrs}$. The count of $L$. acidophilus strains were determined according to ISO 20128:2006 method [15] while enumeration of L.rhamnosus according to ISO 15214:1998 method [16].Further all the recorded results were analyzed using SPSS version 20.

\section{Effect of various whey types on the growth of selected Lactobacilli strains}

Different whey types were used as dissolvent solution in trails of maximum lactobacilli count. Whey types used are: Ras cheese whey water (salted whey) Mozzarella cheese whey water (sweet whey) and acid whey water, all are in combination with sweet potato in the growth medium then adjust $\mathrm{pH}$ to optimum value depended on the previous experiments. Flasks were incubated at $37^{\circ} \mathrm{C}$ Count of lactobacilli strains was calculated by using standard plate count according to ISO 20128:2006 and ISO 15214:1998. Further, the obtained results were analyzed using SPSS version 20. 


\section{RESULT}

\section{Physiochemical analysis of whey water prepared}

Results in Table 3 showed significant differences in physicochemical properties of the directly collected whey water. Total solids of acid whey is higher (W3, 7.23\%) when compared to other whey. Moisture content of salted whey water from vegetable oil and natural Ras cheese, sweet whey from Mozzarella cheese were 94.82\%, $93.53 \%$ and $95.09 \%$ respectively. It is clear that the salted whey water from vegetable oil Ras cheese (W1) contains lower value of lactose $(3.17 \%)$ when compared to other whey used. Salt content of salted whey (W1) is higher than the other used cheese whey.

\section{Kinetics of lactobacilli strains}

Main effect of variables examined in Plackett- Burman design of lactobacilli strains are shown in figure 1 . A p-value less than 0.05 indicates that the mode terms are significant. Addition high concentration $(1 \mathrm{ml} / \mathrm{L})$ of tween 80 to new formed culture media ( trails 7 and 9) has positive effect on growth rate of all L.acidophilus as in figures 1-d,e.while culture media without tween 80 ( trails 4 and 8) were not effect on L. rhamnosus strains growth as shown in figure.s1a,b,c. Addition of Beef extract with low concentration ( $5 \mathrm{~g} / \mathrm{L}$ ) positively influence on all tested strains growth except L. rhamnosus (strain 130RZFAAU) as shown in figure1-b. The presence of $\mathrm{K}_{2} \mathrm{HPO}_{4}(2 \mathrm{~g} / \mathrm{L})$ in the composition of new culture media affects positively on the growth rate of tested probiotics strains LA-5 and SP1, while not adding it did not effect on the growth rate of the other strains. Not adding of $\mathrm{Mg} \mathrm{SO}_{4}$ positively effects on the growth rate of 130 RZFAAU only.

Table3 Physicochemical composition of cheeses whey

\begin{tabular}{|c|c|c|c|c|}
\hline Component & $\begin{array}{c}\text { vegetable oil Ras cheese } \\
\text { whey } \\
\text { (salted whey) } \\
\text { W1 }\end{array}$ & $\begin{array}{l}\text { Ras cheese whey water } \\
\text { (salted whey) } \\
\text { W2 }\end{array}$ & $\begin{array}{c}\text { (acid whey) } \\
\text { W3 }\end{array}$ & $\begin{array}{c}\text { Mozzarella cheese } \\
\text { whey water } \\
\text { (sweet whey) } \\
\text { W4 }\end{array}$ \\
\hline pH & 5.7 & 6.0 & 5.0 & 6.5 \\
\hline Moisture \% & $94.82^{\mathrm{c}}$ & $93.53^{\mathrm{b}}$ & $92.77^{\mathrm{a}}$ & $95.09^{d}$ \\
\hline Total solids \% & $5.18^{\mathrm{b}}$ & $6.47^{\mathrm{c}}$ & $7.23^{\mathrm{d}}$ & $4.91^{\mathrm{a}}$ \\
\hline Lactose \% & $3.17^{\mathrm{a}}$ & $4.03^{\mathrm{b}}$ & $5.61^{\mathrm{d}}$ & $4.13^{\mathrm{c}}$ \\
\hline Salt (Na Cl) \% & $1.91^{\mathrm{b}}$ & $1.8^{\mathrm{b}}$ & $0.3^{\mathrm{d}}$ & $0.15^{\mathrm{a}}$ \\
\hline
\end{tabular}

Means within the same row without a common superscript differ $(\mathrm{P}<0.05)$.

1 Mean values \pm SD of each type of whey water, analyzed in triple.

2 Values reported as mean percentage (wt/wt) of total whey composition.

A 0,25

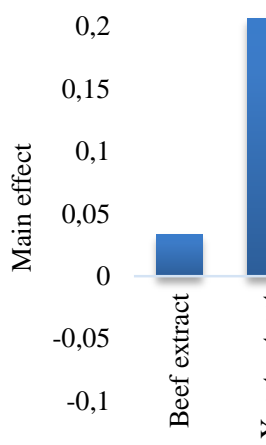

Factors
C 0,3

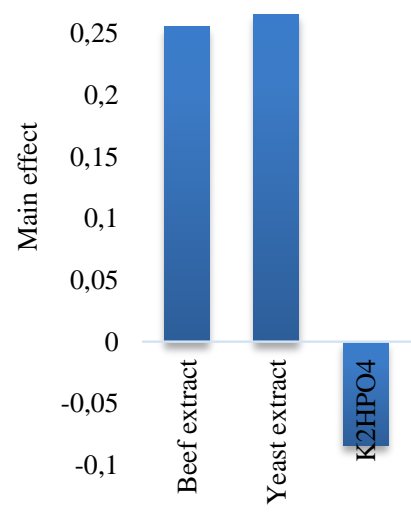

$-0,15$

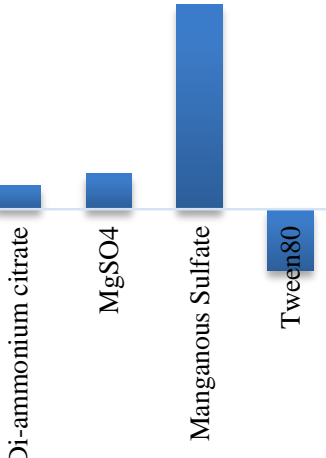

B 0,4

0,3

0

$-0,1$

$-0,2$

\section{L. rhamnosus (130RZFAAU)}

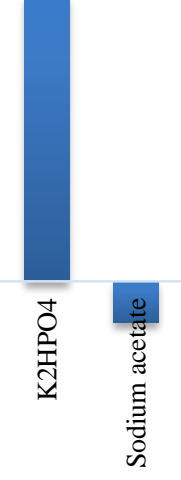

Factors
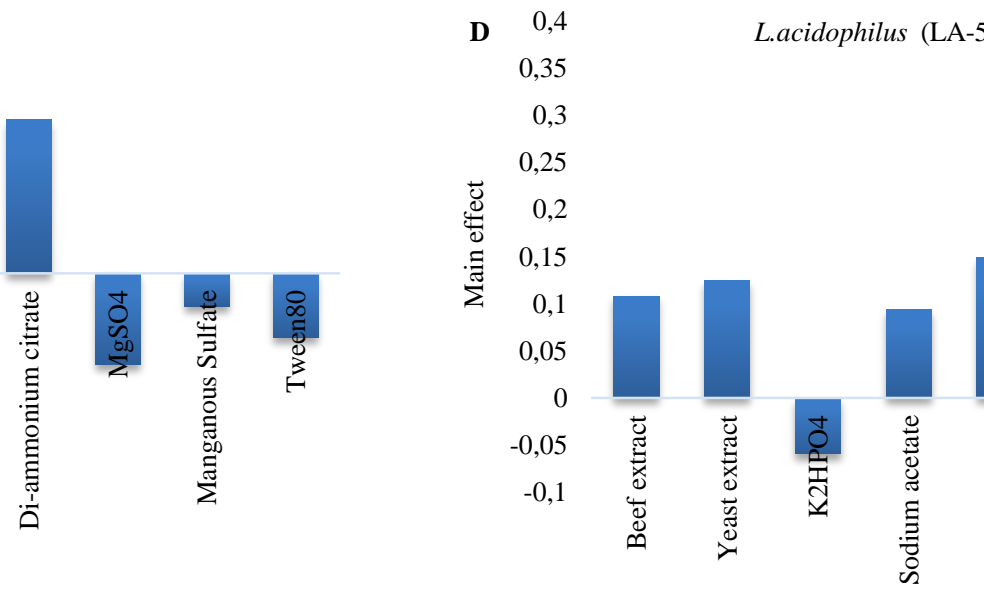

L.rahmnosus (sp1)
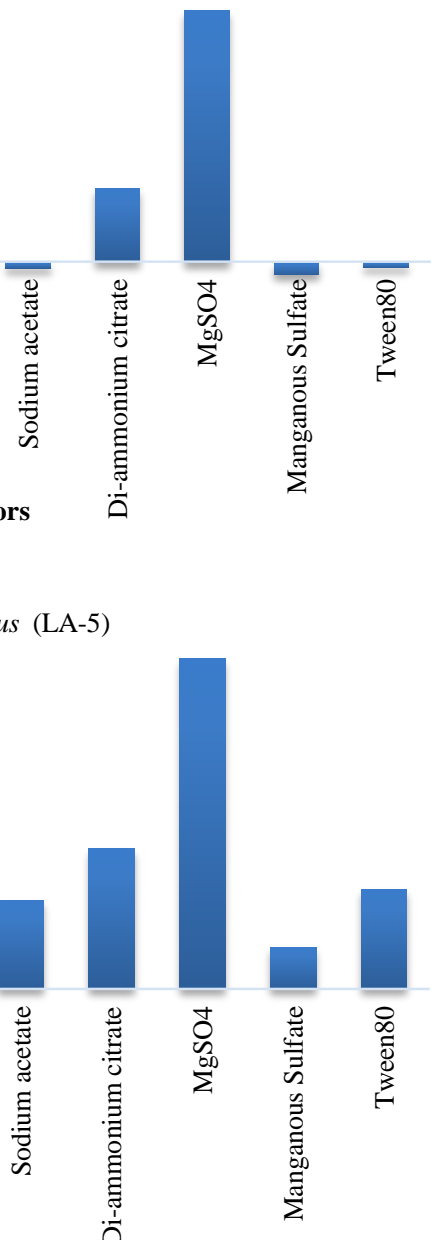
E $\quad 0,3$

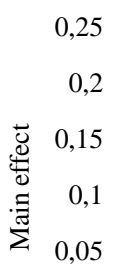

0
L. acidophilus (2r)

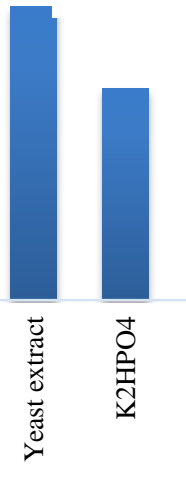

Factors

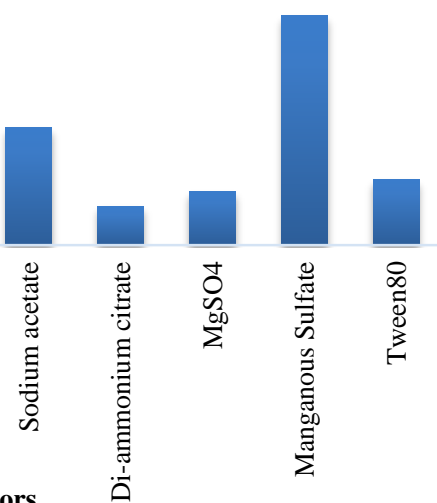

Figure 1 Main effect of factors examined in Plackett-burman statistical design of lactobacilli strains

The pareto chart shows the significant effect of yeast extract in strains (SP1, 190RZFAAU and 2r) as figures 2-a,c,e . Lacidophilus (LA-5 and 2r) is in a critical need for $\mathrm{Mg} \mathrm{SO}_{4}$ for its growth figures 2- d, e.

From Table 4 SPWE medium can achieve highest growth for all tested strains (O.D ${ }_{650}$ : 190RZFAAU was $1.38,130$ RZFAAU was 1.15 , sp1 was 1.33 , LA-5 was 1.34 and $2 \mathrm{r}$ was 1.132

Table 4 Experimental results of the Plackett- Burman design for cell growth rate of Lactobacilli strains after 6h when using sweet potato extract (SPE), water whey (WW) and combination between both.

\begin{tabular}{|c|c|c|c|c|c|c|c|c|c|c|c|c|c|c|c|}
\hline \multirow{3}{*}{ 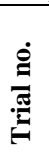 } & \multicolumn{15}{|c|}{ O.D $_{650 \mathrm{~nm}}$} \\
\hline & \multicolumn{3}{|c|}{ 190RZFAAU } & \multicolumn{3}{|c|}{ 130RZFAAU } & \multicolumn{3}{|c|}{ SP1 } & \multicolumn{3}{|c|}{ LA-5 } & \multicolumn{3}{|c|}{$2 r$} \\
\hline & SPE & Ww & $\begin{array}{c}\text { SPW } \\
\text { E }\end{array}$ & SPE & Ww & SPWE & SPE & Ww & $\begin{array}{c}\text { SPW } \\
\text { E }\end{array}$ & SPE & $\mathrm{Ww}$ & SPWE & SPE & Ww & SPWE \\
\hline 1 & 1.330 & 0.897 & 1.096 & 1.08 & 0.29 & 0.23 & 0.59 & 0.35 & 1.334 & 1.20 & 1.11 & 1.12 & 1.12 & 0.637 & 0.93 \\
\hline 2 & 0.130 & 0.563 & 0.856 & 0.65 & 0.50 & 1.01 & 1.00 & 0.60 & 0.559 & 0.20 & 0.20 & 0.430 & 0.312 & 0.155 & 0.38 \\
\hline 3 & 1.08 & 0.851 & 1.12 & 0.42 & 0.29 & 1.05 & 0.90 & 0.17 & 1.256 & 1.01 & 1.00 & 1.210 & 0.786 & 0.459 & 1.032 \\
\hline 4 & 1.306 & 1.025 & 1.28 & 1.08 & 0.23 & 0.78 & 1.09 & 0.15 & 1.34 & 1.10 & 1.13 & 1.09 & 1.066 & 0.877 & 1.045 \\
\hline 5 & 0.96 & 0.753 & 1.120 & 0.67 & 0.25 & 0.25 & 0.87 & 0.29 & 0.98 & 1.01 & 0.47 & 0.823 & 1.123 & 0.419 & 0.793 \\
\hline 6 & 1.25 & 0.676 & 0.918 & 1.07 & 0.28 & 0.66 & 0.63 & 0.40 & 1.25 & 1.32 & 1.08 & 0.988 & 0.469 & 0.583 & 0.762 \\
\hline 7 & 0.456 & 0.530 & 0.962 & 0.96 & 0.60 & 1.15 & 0.90 & 0.81 & 0.735 & 0.30 & 0.21 & 0.803 & 0.474 & 0.160 & 0.838 \\
\hline 8 & 0.480 & 0.793 & 1.38 & 1.03 & 0.37 & 1.07 & 0.93 & 0.72 & 0.733 & 0.62 & 0.39 & 1.020 & 0.434 & 0.381 & 1.132 \\
\hline 9 & 0.369 & 0.925 & 0.870 & 1.06 & 0.59 & 1.01 & 0.72 & 0.66 & 0.832 & 0.54 & 1.05 & 1.340 & 0.574 & 0.528 & 0.569 \\
\hline 10 & 0.710 & 0.886 & 1.073 & 0.82 & 0.47 & 1.02 & 1.10 & 0.55 & 0.620 & 1.00 & 1.01 & 0.690 & 0.472 & 0.637 & 0.95 \\
\hline 11 & 0.767 & 0.481 & 1.090 & 0.41 & 0.29 & 0.58 & 0.98 & 0.24 & 0.977 & 0.67 & 1.02 & 1.043 & 0.74 & 0.384 & 0.655 \\
\hline 12 & 0.721 & 0.800 & 1.013 & 0.42 & 0.44 & 1.01 & 1.16 & 0.55 & 0.925 & 1.04 & 0.34 & 0.743 & 0.479 & 0.729 & 0.789 \\
\hline C & & 1.580 & & & 1.26 & & & 1.60 & & & 1.52 & & & 1.491 & \\
\hline
\end{tabular}

C: control by using MRS SPE: culture media made by sweet potato extract, Ww: culture media made by using whey water, SPWE: culture media made by sweet potato and whey
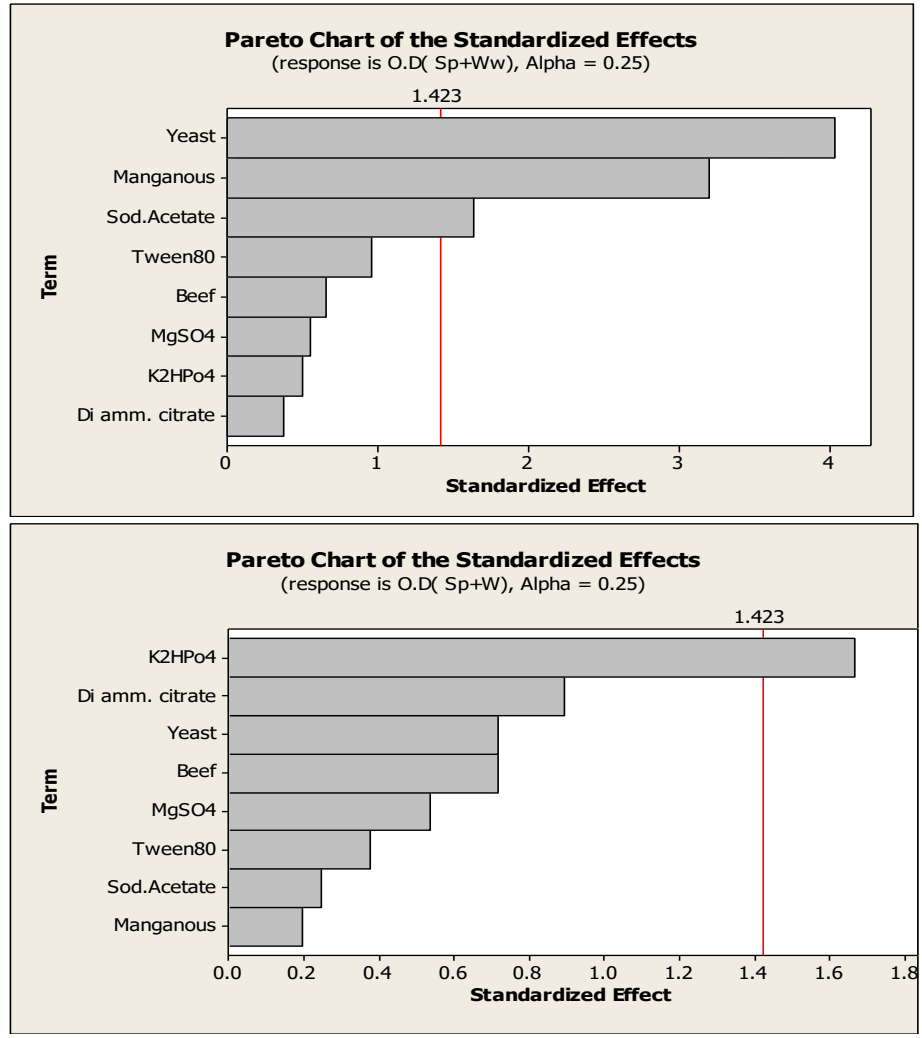

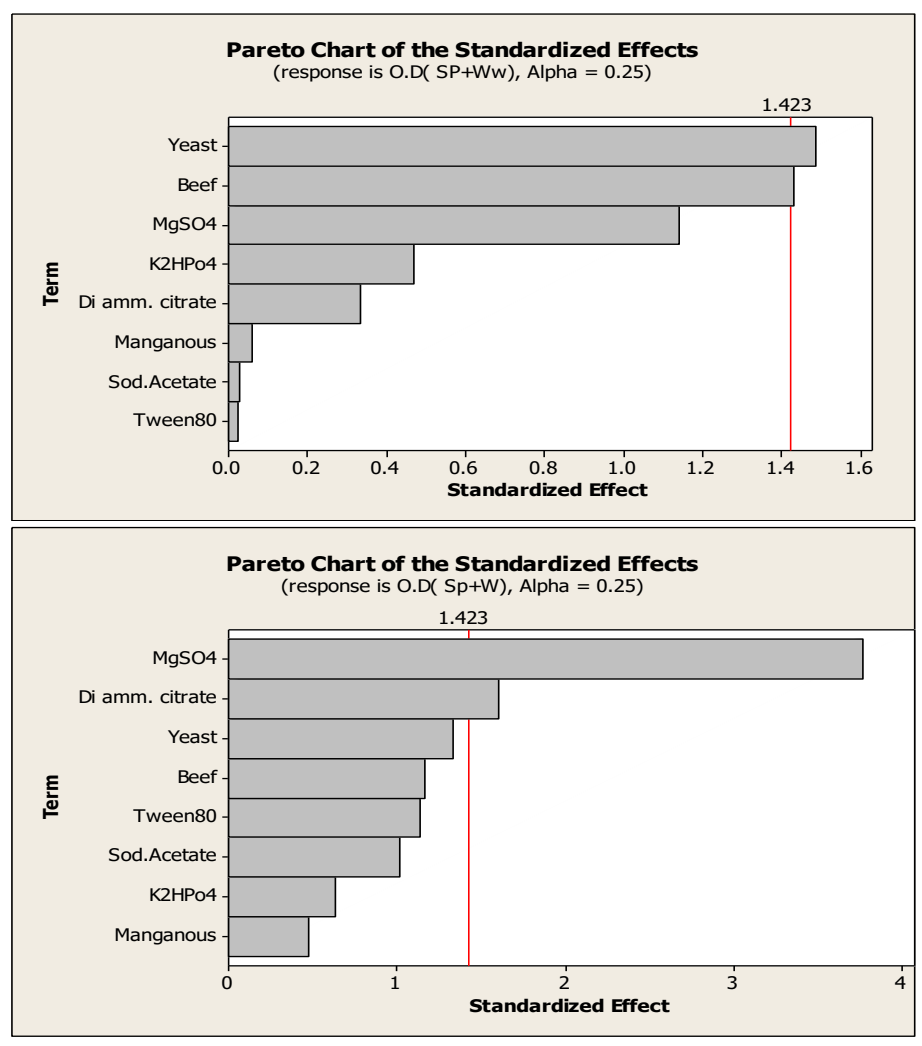




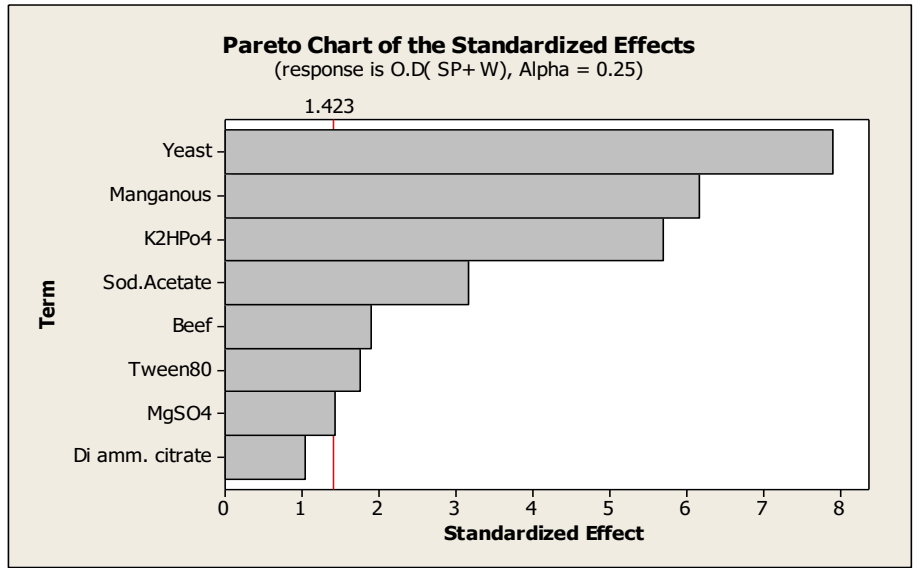

Figure 2 Pareto chart of standardized effects of the different variables tested in plackett- Burman design on growth rate of Lactobacilli strains

\section{Effect of different $\mathrm{pH}$ values}

The results in figure $3(\mathrm{~A}$ and $\mathrm{B}$ ) indicate that the recommended $\mathrm{pH}$ values for achieving the highest growth after $24 \mathrm{~h}$ incubation was 6 and 6.5 for $2 \mathrm{r}$ and 190RZFAAU respectively. The counts for $2 \mathrm{r}$ is $\log 7.58 \pm 0.061 \mathrm{cfu} / \mathrm{ml}$, which exceeds the counts of the control $(\log 6.81 \mathrm{cfu} / \mathrm{g})$. Additionally, the strain 190RZFAAU record maximum count $(\log 9.28 \mathrm{cfu} / \mathrm{ml})$ at $\mathrm{pH} 6.5$, which also significant exceeds than control that record $\log 8.24 \mathrm{cfu} / \mathrm{ml}$.$$
\text { A }
$$$$
\text { L. acidophilus (2r) }
$$

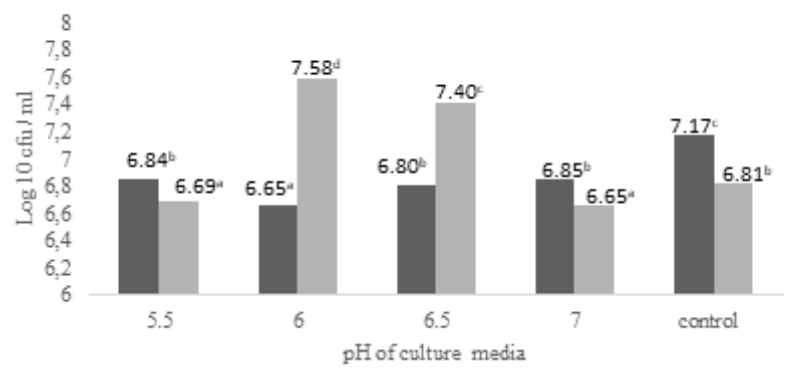

B

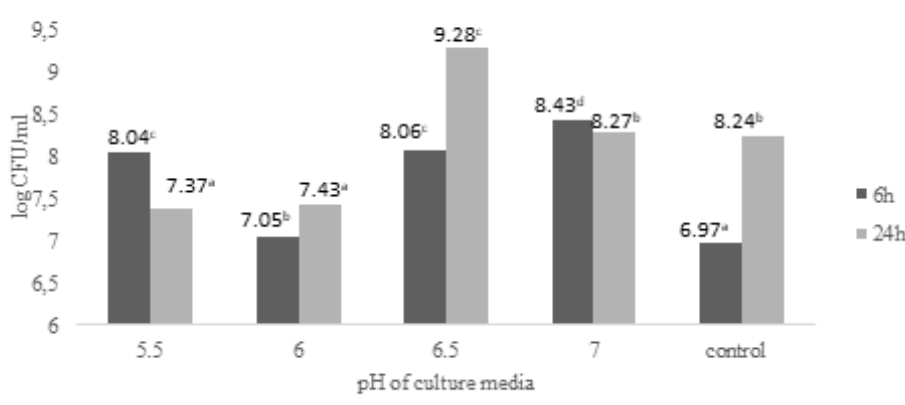

Figure 3 Effect of different $\mathrm{pH}$ on Lactobacilli count $(\log 10 \mathrm{cfu} / \mathrm{ml})$ after $6 \mathrm{~h}$ and $24 \mathrm{~h}$ of incubation at $37^{\circ} \mathrm{C}$

Same letters indicate no significant differences at the $95 \%$ confidence level; different letters at the same color indicate to significant differences at the $95 \%$ confidence level

\section{Effect of whey type on the growth of selected Lactobacilli strains}

Figure 4 shows that the maximum count of 190RZFAAU $(9.28 \mathrm{cfu} / \mathrm{ml})$ when using the SPWE with acid whey followed by the count $(8.75 \mathrm{cfu} / \mathrm{ml})$ that recorded in case of Mozzarella cheese whey water. Then salted whey water recording $(8.66$ and $8.50 \mathrm{cfu} / \mathrm{ml})$ in case of vegetable oil and natural Ras cheese whey water, respectively.

While $2 \mathrm{r}$ had maximum count $(8.53 \mathrm{cfu} / \mathrm{ml})$ with sweet whey water, followed by salted whey water which can record count $(8.41$ and $8.38 \mathrm{cfu} / \mathrm{ml}$ respectively) and acid whey water count $(7.58 \mathrm{cfu} / \mathrm{ml})$. All these results are more significant than that obtained by MRS control medium count $(6.97 \mathrm{cfu} / \mathrm{ml})$ and $(6.81 \mathrm{cfu} / \mathrm{ml})$ in case of $190 \mathrm{RZFAAU}$ and $2 \mathrm{r}$ respectively, after incubation at $37^{\circ} \mathrm{C}$ for $24 \mathrm{~h}$ in broth culture media.

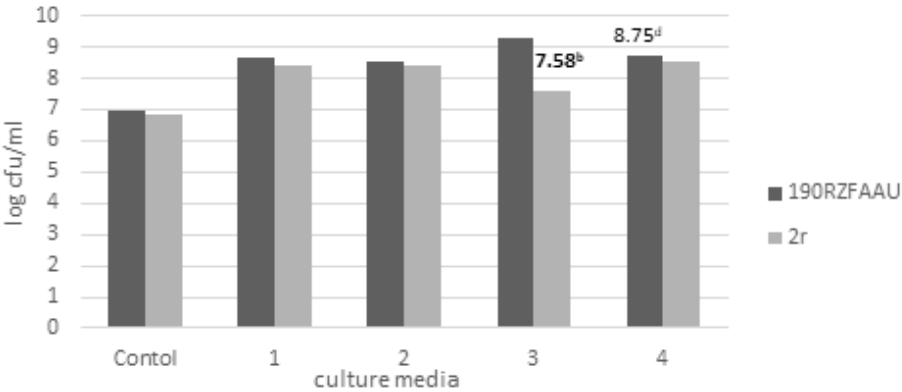

Figure 4 effect of cheese whey type on lactobacilli count

Control: MRS media 1: culture media made by combination of sweet potato and vegetable Ras cheese whey water 2: culture media made by combination of sweet potato and Ras cheese whey water. 3: culture media made by combination of sweet potato and Ricotton cheese whey water 4: culture media made by combination of sweet potato and Mozzarella cheese whey water. Same letters indicate no significant differences at the $95 \%$ confidence level; different letters at the same color indicate to significant differences at the $95 \%$ confidence level

\section{DISSCUSION}

Our present study concluded that, the growth of Lactobacillus strains increased gradually from the zero time until $6 \mathrm{~h}$ of incubation at $37^{\circ} \mathrm{C}$ in all tested media, which was not in accordance with Hayek et al. (2013) who noticed that no growth was indicated during the first $10 \mathrm{~h}$ of incubation.

The present study, recommended applying Plackett- Burman design to improve the optimized medium for Lactobacillus growth, which agrees with Chen $\boldsymbol{e t}$ al (2015), who applied the same experiment to screen the main effective factors for the growth of $L$. acidophilus.

MRS medium is the most common source for cultivation of Lactobacillus sp. because it provides suitable growth factors and nutrition. However, when applied in industry, it has proved to be expensive with a negative impact on the economics of probiotic production or other benefit lactobacilli.

Whey water is used as a new low-cost component in the newly formed lactobacilli media and resulted in a visible growth of the Lactobacilli strains, which can be compared to that, obtained in MRS medium. Whey water, which is available in huge quantities as a waste byproduct of cheese industry can be potentially used as carbon source for cultivation and fermentation of lactobacilli. Our results are in agreement with Ansari et al.,2017 whose experiments were carried out on L.sporogenes and L.acidophilus strains using the whey water as a potentially low-cost Lactobacillus production media. The results indicating that the growth of these species was comparable to that of MRS medium.

Our Plackett- Burman study on the growth of L. acidophilus (strain $2 \mathrm{r}$ and strain LA-5) in SPWE medium; suggested that, high levels of all media components positively influences on growth rate. In pareto chart, the most significant components had effect on the growth rate of L.acidophilus (2r) yeast extract followed by MnSO4, K2HPO4, sodium acetate, beef extract, tween80 and $\mathrm{MnSO}_{4}$, respectively. Di-ammonium citrate was not significant when compared to the significance degree of all other medium components. The results of the present study are in agreement with Chen et al. (2015) who applied the PlackettBurman experiment to screen the main effective factors for L. acidophilus production; the results indicated that $\mathrm{K}_{2} \mathrm{HPO}_{4}$ was a significant growth factor, also, $\mathrm{K}_{2} \mathrm{HPO}_{4}$ and sodium acetate were important factors with +ve effect on the growth of L. acidophilus.

Our statistical and practical studies on L. acidophilus (strain LA-5) grown in SPWE, indicated that; $\mathrm{MgSO}_{4}$ then Di-ammonium citrate had a significant effect on the growth rate. However, high levels of beef extract, yeast extract, sodium acetate, Di-ammonium citrate, $\mathrm{MgSO}_{4}, \mathrm{MnSO}_{4}$ and tween80 in the growth medium affects growth rate of $L$. acidophilus (strain LA-5) positively. On the other hand, the presence of $\mathrm{K}_{2} \mathrm{HPO}_{4}$ at the lowest level would result in high growth rate, as reported by Cox, 2007. the significance of each variable coefficient was expressed by the probability value ( $\mathrm{p}$-value).

The variation observed in the previous results among the most significant factors and the level of the medium components may be due to the newly tested combination between sweet potato and whey water in the formed medium, which may have a critical effect on the growth of L. acidophilus strains.

In our statistically designed medium, $\mathrm{MnSO}_{4}$ is used in a very small amount ranges from 0 to $0.05 \mathrm{~g} / \mathrm{l}$, which is in complete agreement with Adthalungrong et al.(2014) who stated that, sweet potato hydrolysate may contain few amounts of $\mathrm{MnSO}_{4} \cdot \mathrm{H}_{2} \mathrm{O}$ which suffice the minimum needs for $\mathrm{Mn}^{2+}$ as LAB needs trace amounts of this cofactor for growth and acid production. In addition, the field of study made by Adthalungrong et al.(2012) suggested that, over $90 \%$ of reducing sugars in sweet potato hydrolysate was glucose, an easily utilized carbon source for most microorganisms.

In our experiments, we are reporting the necessity of $L$. acidophilus and $L$. rhamnosus growth by $\mathrm{Mn}^{2+}$ and $\mathrm{Mg}^{2+}$ for that; the newly formed medium 
contains these metal ions $\mathrm{Mn}^{2+}$ and $\mathrm{Mg}^{2+}$. In accordance to our investigations, Hayek et al.,2013, noticed that the growth of L. reuteri was enhanced by $\mathrm{Mn}^{2+}$ and $\mathrm{Mg}^{2+}$ which can be explained by that these metal ions are necessary for Lactobacillus growth (Boyaval,1989; Letort and Juillard,2001; Wegkamp et al.,2010). $\mathrm{Mn}^{2+}$ assists the cell to deal with the reactive oxygen species and serves as an alternative for the absence of a gene encoding a superoxide dismutase (Wegkamp et al.,2010). $\mathrm{Mg}^{2+}$ was earlier found to activate the growth of Lactobacillus and enhance its survival (Amouzou et al.,1985). It was shown that $\mathrm{Mg}^{2+}$ is the only essential oligoelement for the growth of $L$. delbruecki subsp. Lactis (Hébert et al.,2004). $\mathrm{Mg}^{2+}$ and $\mathrm{Mn}^{2+}$ were found to be essential critical minerals for L. plantarum growth (Wegkamp et al..,2010)

Concerning detecting the optimum $\mathrm{pH}$ value for obtaining maximum Lactobacillus count. The results indicated that 6 and 6.5 are the recommended $\mathrm{pH}$ values for achieving the highest growth after $24 \mathrm{~h}$ incubation for the two selected lactobacilli strains; L. acidophilus (2r) and L. rhamnosus (190RZFAAU) respectively, as the cell count for the first strain was recorded to be $\log 7.58 \mathrm{cfu}$ $/ \mathrm{ml},$. Additionally, the strain L. rhamnosus (190RZFAAU) record maximum cell count $\log (9.28) \mathrm{cfu} / \mathrm{ml}$ at $\mathrm{pH}$ 6.5, This could be the same view of Goderska $\boldsymbol{e}$ al. (2008) due to that; Lactobacillus is a genus of LAB characterized by fermenting sugars to energy and lactic acid within the growth. In addition, there is a relation between the growth and the $\mathrm{pH}$ that can be +ve or -ve based on the favorable $\mathrm{pH}$ of the microorganism. Generally, the relation between the $\mathrm{pH}$ and the lactic acid bacteria population is inversely proportional. Many Lactobacillus strains can grow at optimum $\mathrm{pH}$ value ranging from 5.0 and 6.0 , but also can survive at $\mathrm{pH} 4.4$ as concluded by (Lahtinen et al.,2011). In accordance with our results (Ansari et al.,2017) stated that $\mathrm{pH} 6$ was the optimum $\mathrm{pH}$ value for growth of L. acidophilus.

From our study, the final recommend optimized media is sweet potato whey extract media (SPWE) supplemented with beef extract, yeast extract ,diammonium citrate and magnesium sulfate. The media $\mathrm{pH}$ adjusted to 6-6.5. For Lactobacillus acidophilus cultivation, tween 80 should be added to the previous components. While di potassium phosphate, sodium citrate and manganese sulfate could be used in respect of the selected strains

Although the various types of cheese whey (salted, acid and sweet) were suitable for using in culture media to lactobacilli enumeration, there were significant differences among cheeses whey water in its effect on lactobacilli count. These differences may be due to the differences in chemical composition. It was clear that, acid whey water was the best for L.rhamnosus enumeration; due to high lactose content $(5.6 \%)$ compared to other whey used. In addition, acid whey may contain citric acid which has a positive effect on the growth of L. rhamnosu (Jyoti et al., 2004) stated that; increasing of lactose in acid whey may refer to evaporation of whey during heat treatment and coagulation by lemon juice.

\section{CONCLUSION}

The present investigations recommended the newly designed cheap medium for growth of Lactobacillus instead of other expensive chemical media as MRS. Our newly formed optimized medium turned out to be economically viable as its production price is cheaper than that of MRS medium and its cultivation amount is also close to that of the MRS medium.

Possibility to use a new statistical software (Mini Tab 16) in applying the Plackett -Burman design; to assess the effects of the newly formed medium components on the growth of L. acidophilus and L. rhamnosus, and study their optimum levels to maximize the growth of studied strains.

Conflict of Interest: No conflict of interest declared.

\section{REFRENCES}

Adthalungrong, A., Adthalungrong, C., Sangsuwan, K., \& Ruenchon, M. (2012) Production of glucose syrup from sweet potato by enzymatic processes. The 24th Annual Meeting of the Thai Society for Biotechnology: Ubon Ratchathani University, Thailand.

Adthalungrong, A., Adthalungrong, C., Sirithanachareon, A., \&Prachansit,A (2014). Lactic acid production from sweet potato by Lactobacillus casei tistr 453 GTAR,14(1),162-172.

Amouzou, K.-S., Prevost, H., \& Divies, C. (1985). Influence de la supplémentation du lait en magnésium sur la fermentation lactique réalisée par $\mathrm{S}$. lactis et S. thermophilus. Le Lait, 65(647-648), 21-34. http://dx.doi:10.1051/lait:1985647-6482

Ansari, N. F., Chetana, A., Prasad, E. M., Birajdar, R., \&Naidu, N.V. (2017) Evaluation of whey water as growth medium for Lactobacillus species. International Journal of Applied Biology and Pharmaceutical Technology., 8(1),38-42.

Association of Official Analytical Chemists (2005). Official Methods of Analysis. 18th ed. AOAC Int., Gaithersburg, MD: https://www.researchgate.net/publication/292783651_AOAC_2005

Awad, S., Ahmed, N. E., \& Soda, M. E. (2013). Application of Salt Whey from Egyptian Ras Cheese in Processed Cheese Making. Food and Nutrition Sciences, 04(09), 79-86. http://dx.doi:10.4236/fns.2013.49a2011
Boyaval, P. (1989). Lactic acid bacteria and metal ions. Le Lait, 69(2), 87-113. http://dx.doi:10.1051/lait:198927

Chandrapala, J., Duke, M. C., Gray, S. R., Zisu, B., Weeks, M., Palmer, M., \& Vasiljevic, T. (2015). Properties of acid whey as a function of $\mathrm{pH}$ and temperature. Journal of Dairy Science, 98(7), 4352-4363. doi:10.3168/jds.2015$\underline{9435}$

Chen, H., Niu, J., Qin, T., Ma, Q., ... Wang, L. (2015). Optimization of the medium for Lactobacillus acidophilus by Plackett-Burman and steepest ascent experiment. Acta Scientiarum Polonorum Technologia Alimentaria, 14(3), 227 232. http://dx.doi:10.17306/j.afs.2015.3.24

Cox, D. R. (2007). Response Surfaces, Mixtures, and Ridge Analyses, 2nd Edition by George E.P. Box, Norman R. Draper. International Statistical Review, 75(2), 265-266. http://dx.doi:10.1111/j.1751-5823.2007.00015_17.x

Duda-Chodak ,A., Tarko, T., \& Statek, M. (2008). The effect of antioxidants on Lactobacillus casei cultures. Acta Scientiarum Polonorum, Technologia Alimentaria.,7(4),39-51.

El - Tanboly, E., El-Hofi, M., Bahr, Y., El-Desoki, W., \& Ismail, A. (2012). Uutilization of salt whey from Egyptian ras (cephalotrye) cheese in microbial milk clotting enzymes production. Journal of Food and Dairy Sciences, 3(5), 299-314. http://dx.doi:10.21608/ifds.2012.75391

Goderska, K., Nowak, J., \& Czamecki, Z. (2008). Comparison of growth of Lactobacillus acidophilus and Bifidobacterium bifidum species in media supplemented with selected saccharides including prebiotics. Acta Scientiarum Polonorum, Technologia Alimentaria,7 (2), 5-20.

Hayek, S. A., Shahbzi, A., Awaisheh, S. S., Shah, N. P., \& Ibrahim, S. A. (2013). Sweet Potatoes as a Basic Component in Developing a Medium for the Cultivation of Lactobacilli. Bioscience, Biotechnology, and Biochemistry, 77(11), 2248-2254. http://dx.doi:10.1271/bbb.130508

Hébert, E. M., Raya, R. R., \& Giori, G. S. de. (2004). Nutritional Requirements of Lactobacillus delbrueckii subsp. lactis in a Chemically Defined Medium. Current Microbiology, 49(5), 341-345. http://dx.doi:10.1007/s00284-004-4357-9 Ibrahim, A., \& Awad, S. (2017). Selection and identification of protective culture for controlling Staphylococcus aureus in fresh Domiati like cheese. Journal of Food Safety, 38(1). http://dx.doi:10.1111/jfs.12418

International standard ISO 20128:2006. Milk products enumeration of presumptive lactobacillus acidophilus on a selective medium - colony coun technique at $37^{\circ} \mathrm{C}$, Switzerland: https://www.iso.org/standard/35292.html International standard ISO 15214:1998. Microbiology of food and animal feeding stuffs-Horizontal method for the enumeration of mesophilic lactic acid bacteriacolony count technique at $30^{\circ}$ C, Switzerland:https://www.iso.org/standard/26853.html

Jyoti, B. D., Suresh, A. K., \& Venkatesh, K. V. (2004). Effect of preculturing conditions on growth of Lactobacillus rhamnosus on medium containing glucose and citrate. Microbiological Research, 159(1), 35-42. http://dx doi:10.1016/j.micres.2004.01.008

Leroy, F., \& De Vuyst, L. (2004). Lactic acid bacteria as functional starter cultures for the food fermentation industry. Trends in Food Science \& Technology, 15(2), 67-78. http://dx. doi:10.1016/j.tifs.2003.09.004

Letort, C., \& Juillard, V. (2001). Development of a minimal chemically-defined medium for the exponential growth of Streptococcus thermophilus. Journal of Applied Microbiology, 91(6), 1023-1029. http://dx. doi:10.1046/j.13652672.2001.01469.x

Mahrous,H.,\& Abd-El-Salam,R. (2014).Production of a functional frozen yoghurt fortified with omega-3 and vitamin E. American journal of food and nutrition, 2 , (5) ,77-84. https://dx.doi. org/10.12691/ajfn-2-5-1

Loebenstein, G., \& Thottappilly, G. (Eds.). (2009). The Sweetpotato.Springer, Belgium,189-234.http://dx.doi:10.1007/978-1-4020-9475-0

Plakckett, R. L., \& Burman, J. P. (1946). The design of optimum multifactorial experments. Biometrika, 33(4), 305-325. http://dx.doi:10.1093/biomet/33.4.305

Ryan, M. P., \& Walsh, G. (2016). The biotechnological potential of whey. Reviews in Environmental Science and Bio/Technology, 15(3), 479-498 http://dx.doi:10.1007/s11157-016-9402-1

Shah, N.P.(2004). Probiotics and prebiotics. Agro Food Industry Hi-Tech 15(2004), 13-16

Shori, A. B. (2016). Influence of food matrix on the viability of probiotic bacteria: A review based on dairy and non-dairy beverages. Food Bioscience, 13 1-8. http://dx.doi:10.1016/j.fbio.2015.11.001

Lahtinen, S., Ouwehand, A. C., Salminen, S., \& von Wright, A. (Eds.). (2011). Lactic Acid Bacteria. London, 1-17. http://dx.doi.org/10.1201/b11503-3

Wegkamp, A., Teusink, B., De Vos, W. M., \& Smid, E. J. (2010). Development of a minimal growth medium for Lactobacillus plantarum. Letters in Applied Microbiology, 50(1), 57-64. http://dx.doi:10.1111/j.1472-765x.2009.02752.x 